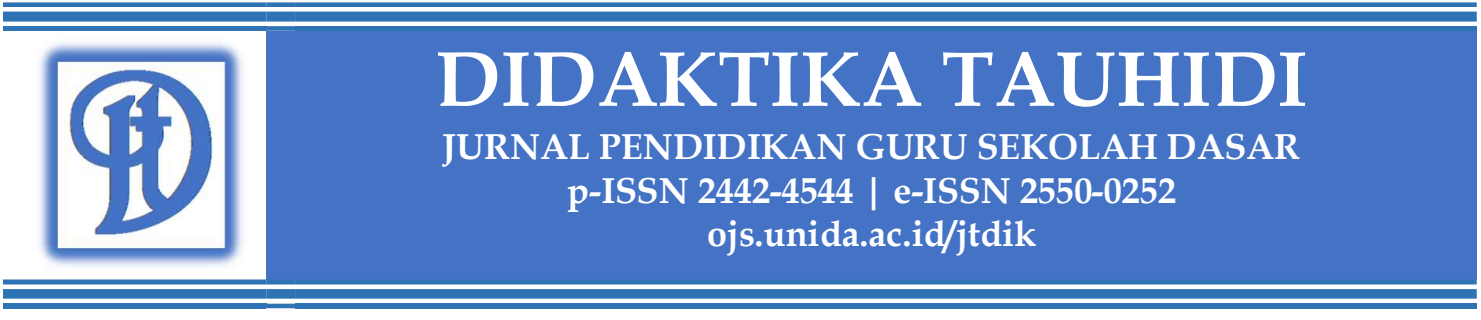

\title{
Penggunaan Model Pembelajaran 4.0 Bagi Tenaga Pendidik Sekolah Dasar Jakarta
}

\author{
Nurrohmatul Amaliyah \\ Pendidikan Dasar, Pascasarjana \\ Universitas Muhammadiyah Prof. Dr. HAMKA \\ Jl. Limau II, RT.3/RW.3, Kramat Pela, Kec. Kby. Baru, Kota Jakarta Selatan, \\ Daerah Khusus Ibukota Jakarta 12130
}

Volume 8 Nomor 1

April 2021: 43-54

DOI: $10.30997 / d t . v 8 i 1.3342$

Article History

Submission: 27-10-2020

Revised: 01-01-2021

Accepted: 25-04-2021

Published: 29-04-2021

Kata Kunci:

Peran Guru, Model Pembelajaran,

Revolusi Industri 4.0

Keywords:

The Role of Teachers, Learning

Models, Industry 4.0

Korespondensi:

Nurrohmatul Amaliyah

Telp. 081313368872

nurramaliyah@uhamka.ac.id
Abstrak: Tujuan penelitian adalah untuk mengungkapkan penggunaan model pembelajaran 4.0 pada guru SD di wilayah DKI Jakarta. Penelitian ini menggunakan metode studi kasus. Pengumpulan data menggunakan teknik observasi, kuesioner dan wawancara. Dalam menganalisis data digunakan teknik analisis deskriptif. Hasil penelitian menunjukan bahwa guru belum sepenuhnya menjadi mediator dan inspirator yang aktif dalam pemanfaatan teknologi pada praktik pembelajaran era 4.0 di wilayah DKI Jakarta, kemudian praktik pembelajaran masih berorientasi pada metode konvensional yang berpusat pada guru, evaluasi pembelajaran pun belum berbasis media interaktif karena terbatasnya kemampuan guru dalam memanfaatkan penggunaan aplikasi interaktif berbasis teknologi terbarukan. Kemudian faktor pendorong praktik pembelajaran era revolusi industri 4.0 yaitu tersedianya sarana pendukung pembelajaran berbasis internet, dukungan kepala sekolah dan kemudahan dalam mengakses informasi dan komunikasi. Kemudian faktor penghambat yang ditemukan yaitu terbatasnya kemampuan guru dalam mengaplikasikan teknologi pembelajaran, minat belajar siswa yang rendah dan terbatasnya sarana pendukung yang dimiliki guru.

\section{Application of 4.0 Learning Model for Jakarta Primary School Educators}

Abstract: The research objective was to reveal the use of the 4.0 learning model for elementary school teachers in the DKI Jakarta area. This research uses a case study method. Collecting data using observation techniques, questionnaires, and interviews. In analyzing the data using descriptive analysis techniques. The results of the study show that teachers have not fully become mediators and inspirations who are active in the use of technology in the era 4.0 learning practices in the DKI Jakarta area, then learning practices are still oriented towards conventional teacher-centered methods, learning evaluation has not been based on interactive media because of the limited ability of the teacher. in utilizing the use of interactive applications based on renewable technology. Then the driving factors for the practice of learning in the era of the industrial revolution 4.0 are the availability 
of internet-based learning support facilities, the support of the principal, and the ease of accessing information and communication. Then the inhibiting factors found were the limited ability of teachers to apply learning technology, low student interest in learning, and limited supporting facilities owned by the teacher

\section{PENDAHULUAN}

Pendidikan dapat berarti sebuah usaha yang dilakukan manusia, dalam membentuk suatu pribadi yang utuh. Di samping itu juga pendidikan merupakan sarana yang dianggap paling mumpuni untuk menciptakan dan mencetak peserta didik yang lebih baik di kemudian hari. Oleh karena itu Indonesia memposisikan pendidikan sebagai suatu hal penting yang menjadi dasar dalam pembangunan bangsa. Berbagai kebijakan dalam mewujudkan pendidikan yang relevan dengan kemajuan zaman terus diupayakan pemerintah. Termasuk didalamnya mendorong guru untuk mampu melibatkan teknologi dalam praktik mengajar di era 4.0.

Sesungguhnya langkah pemerintah dalam arah pendidikan Indonesia tersebut selaras temuan Soenarno Murni (Soenarno, 2019) mengenai industri 4.0 yang berbasis digital sibernetik disamping jaringan big datanya terkoneksi dengan cepat dan luas jangkauannya. Kemajuan pesat pada era 4.0 ini sesungguhnya menjadi tantangan bagi pendidikan di Indonesia untuk mampu memfasilitasi terciptanya pendidikan yang mampu memenuhi tuntutan tersebut.

Guru sebagai fasilitator kegiatan pembelajaran menjadi garda terdepan dalam memfasilitasi peserta didik melalui pembelajaran yang relevan dengan tuntutan era 4.0. Hal ini sebagaimana yang dikemukakan oleh Hartati (Hartati, 2019) bahwa guru menghadapi tantangan besar dalam zaman revolusi industri 4.0. Guru harus sigap namun luwes, ini menunjukan bahwa guru harus mampu melakukan penyesuaian diri dalam waktu yang singkat, dengan berbagai pertimbangan yang ada. Selain pemahaman teoritis, guru juga harus memiliki kemampuan dalam mempraktekkan pembelajaran di era 4.0 ini. Pemahaman mengenai model pembelajaran mutakhir sebagai center point dari upaya untuk menghadapi era revolusi 4.0 ini kini menjadi sebuah keharusan. Selain itu implementasinya pun kini tidak dapat 
dielakan lagi. Guru harus mampu menyajikan sebuah pembelajaran berbasis model pembelajaran era $4.0 \mathrm{di}$ persekolahan.

Berdasar hal tersebut penting dilakukan penelitian tentang penggunaan model pembelajaran 4.0 guru. Hasil penelitian ini akan memberikan deskripsi mengenai bagaimana para guru menggunakan model pembelajaran yang pembelajaran di era 4.0. Selain itu temuan penelitian ini pula akan menyajikan gambaran mengenai bagaimana respon guru dalam mempraktekkan pembelajaran di era 4.0.

Pada penelitian ini peneliti memfokuskan diri untuk mengkaji bagaimana penggunaan model pembelajaran pada kegiatan belajar mengajar yang dilakukan oleh guru Sekolah Dasar di DKI Jakarta di era 4.0.

\section{METODE}

Penelitian ini menggunakan pendekatan kuantitatif dengan metode studi kasus. Adapun teknik pengumpulan data menggunakan observasi, wawancara dan kuesioner. Analisis data menggunakan teknik analisis deskriptif yang menyajikan gambaran temuan penelitian mengenai objek yang menjadi fokus penelitian (Sugiyono, 2018). Teknik tersebut menjadi mata analisis untuk mengungkapkan bagaimana penggunaan model pembelajaran di era 4.0 diimplementasikan oleh guru di wilayah DKI Jakarta.

Populasi penelitian ini adalah guruguru di SDN wilayah DKI Jakarta. Adapun sampel diambil dari tiap wilayah DKI Jakarta yang terdiri dari Jakarta Barat, Jakarta Timur, Jakarta Selatan dan Jakarta Pusat yang masingmasing diambil tiga Sekolah Dasar yang mewakili populasi penelitian.

Berikut bagan alur dalam penelitian ini:

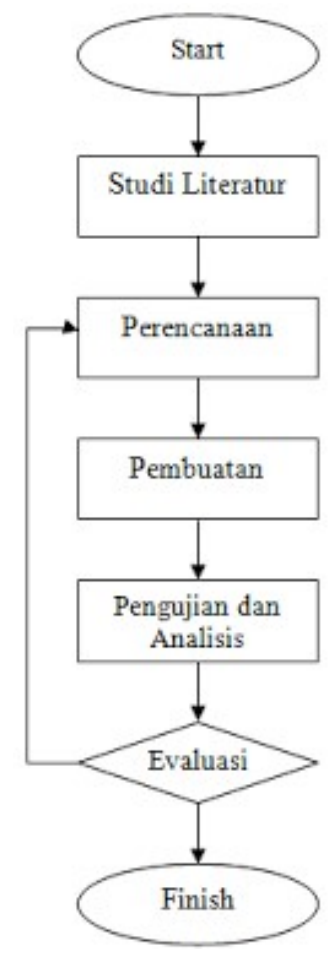

Gambar 1 Alur Penelitian 
Penggunaan Model Pembelajaran 4.0 Bagi Tenaga Pendidik ...

HASIL \& PEMBAHASAN

Hasil yang didapat dalam penelitian ini yaitu berupa: (1) Implementasi proses belajar yang terjadi di kelas; (2) Evaluasi proses pembelajaran yang ada di kelas; (3) Faktor pendukung dan penghambat yang terdapat dalam kegiatan pembelajaran.

\section{Hasil}

Hasil penelitian didapat bahwa terdapat beberapa guru yang dalam pelaksanaan pembelajarannya masih menggunakan metode konvensional. Hal ini sebagaimana hasil wawancara pada Maret 2020 dengan guru kelas IV SDN Cakung Barat 7 yang menemukan bahwa guru tidak berani untuk keluar dari zona nyamannya dalam menggunakan metode ceramah. Guru terlalu nyaman untuk mengubah gaya mengajarnya meskipun sesungguhnya guru tersebut mengetahui bahwa kemajuan fasilitas pembelajaran telah banyak ditemukan di era revolusi industri 4.0 untuk membantu guru dalam kegiatan pembelajaran seperti Google Classroom serta aplikasi-aplikasi pembelajaran lain dan metode-metode pembelajaran terbarukan lainnya.
Selanjutnya berdasarkan data wawancara dan observasi yang dilakukan pada bulan April 2020 di SDN Pekayon 05 Pagi menemukan fakta yang sama dengan temuan pada praktik wawancara sebelumnya. Peneliti menemukan bahwa terdapat guru yang masih mempergunakan model pembelajaran konvensional seperti model pembelajaran ceramah serta ditemukan bahwa capaian belajar siswa cenderung kurang. Metode pembelajaran tersebut yang guru lakukan di SDN Pekayon 05 Pagi justru mengakibatkan siswa menjadi tidak aktif selama kegiatan belajar karena kurang adanya keterlibatan siswa selama kegiatan belajar berlangsung. Penggunaan metode ceramah justru akan mengarahkan pembelajaran hanya berpusat pada materi tanpa memperdulikan aktif tidaknya siswa dalam pembelajaran. Temuan tersebut menunjukan bahwa pembelajaran konvensional tidak selaras dengan tuntutan pembelajaran era 4.0 yang memandang siswa sebagai objek yang aktif dalam kegiatan pembelajaran. Berdasarkan hal tersebut, pada praktik pembelajaran guru seyogyanya berperan sebagai fasilitator yang 
menciptakan kegiatan pembelajaran yang efektif guna mendorong aktivitas belajar siswa.

Ada pula temuan penelitian pada Maret 2020 di SDN Cakung Barat, selama proses pelaksanaan pembelajaran berlangsung peneliti menemukan bahwa guru melakukan praktik pembelajaran dengan asumsi bahwa siswa diberi ilmu pengetahuan hanya dengan diberi ceramah saja. Kegiatan siswa hanya berkutat pada duduk dengan tenang, mendengarkan penjelasan guru, dan sesekali mencatat hal-hal yang diperintahkan oleh gurunya. Bagian yang dirasa paling fatal adalah pembelajaran cenderung membosankan sehingga kurang membangkitkan gairah belajar siswa. Siswa hanya diposisikan sebagai objek yang harus menghafal materi yang cukup banyak tanpa benar-benar memahami esensi yang dipelajarinya. Pembiaran kondisi tersebut sesungguhnya akan berakibat pada makin menurunnya motivasi maupun capaian belajar peserta didik.

Berdasarkan data penelitian di atas dapat diketahui bahwa saat ini guru cenderung belum siap dengan perubahan dari metode konvensional menuju metode pembelajaran berbasis teknologi mutakhir. Namun pada kondisi pandemi Covid-19 saat ini guru dituntut untuk mampu menerapkan sistem daring yang mau tidak mau memaksa para guru untuk merubah dirinya dari sistem pembelajaran konvensional ke pembelajaran berbasis teknologi. Oleh sebab itu, kini banyak guru yang melaksanakan pembelajaran daring melalui media sosial WhatsApp Group.

Pembelajaran melalui WhatsApp Group sesungguhnya dapat menjadi pemantik bagi guru untuk berinovasi dalam praktik mengajarnya. Akan tetapi kenyataan di lapangan justru guru hanya memberikan penugasan tanpa memanfaatkan metode dan media pembelajaran yang sesungguhnya dapat memudahkan guru dalam melaksanakan pembelajaran secara online (Anggraeni, 2018).

Selain itu, pembelajaran daring ini pula sesungguhnya dapat mendorong guru untuk mulai memanfaatkan kecanggihan teknologi dalam model $e$ learning. Sistem tersebut dapat diartikan sebagai model pembelajaran penggunaan pemanfaatan teknologi 
Penggunaan Model Pembelajaran 4.0 Bagi Tenaga Pendidik ...

komunikasi dan informasi (Hanum, 2013). Oleh karena itu, guru dapat mengeksplorasi berbagai media atau aplikasi yang mendukung pembelajaran berbasis e-learning seperti Ruang Guru, Edmodo dan Zenius.net.

Pembelajaran daring yang saat ini dilakukan guru di masa pandemi dapat dilihat sebagai sebuah kesempatan bagi guru untuk menyesuaikan diri dengan praktik pengajaran di era 4.0 yang pada dasarnya berbasis teknologi internet. Pembelajaran pada era 4.0 yang mengusung konsep fleksibel dan efisien tidak lagi relevan dengan metode konvensional yang biasanya menjadi andalan guru dalam mengajar. Hal ini karena pada pembelajaran era 4.0 semua proses pembelajaran cenderung memanfaatkan internet sehingga belajar mengajar dapat dilakukan tanpa terbatas jarak maupun waktu, pemanfaatan video berisi penjelasan tentang materi yang diajarkan, latihan soal, dan tryout online menjadi bagian praktik pembelajaran era 4.0.

Temuan penelitian selanjutnya mengenai pelaksanaan evaluasi pembelajaran ditemukan bahwa banyak guru yang hanya melakukan evaluasi berupa pengerjaan soal di lembar jawaban saja. Berdasarkan temuan diketahui bahwa ada variasi teknik dalam hal evaluasi pembelajaran yang melibatkan penggunaan teknologi. Melihat pada fakta tersebut, praktik evaluasi dilakukan secara konvensional dan jarang melibatkan penggunaan teknologi. Padahal evaluasi pembelajaran dapat dilaksanakan melalui beragam inovasi. Baik inovasi pada metode pembelajarannya, maupun pada media pembelajarannya. Sebagai contoh, metode pembelajaran permainan dan inkuiri dapat membuat evaluasi pembelajaran berlangsung secara interaktif. Bentuk baru dari evaluasi pembelajaran ini ditujukan agar anak mampu berpikir secara kritis tentang materi yang disampaikan selama proses pembelajaran.

Berdasarkan temuan wawancara yang sebelumnya telah dilakukan, diketahui bahwa guru menemui kesulitan dalam menyusun instrumen evaluasi sehingga guru cenderung menggunakan soal-soal terdahulu yang sudah sering digunakan dan tidak memperhatikan perubahan tuntutan capaian akademik siswa yang setiap tahunnya berubah menyelaraskan dengan perkembangan zaman. Kondisi 
p-ISSN 2442-4544 | e-ISSN 2550-0252 || 49

DOI: $10.30997 /$ dt.v8i1.3342

tersebut berdampak pada praktik evaluasi yang tidak relevan dengan kebutuhan sehingga analisis hasil belajar tidak dapat dilakukan secara optimal.

Selain keterbatasan kemampuan guru dalam membuat instrumen evaluasi, temuan penelitian menunjukan bahwa guru pun mengalami kesulitan dalam menggunakan media interaktif pada pelaksanaan evaluasi. Hambatan tersebut didasari oleh keterbatasan pemahaman guru mengenai variasi model evaluasi berbasis teknologi.

Selanjutnya temuan penelitian mengenai faktor pendukung dan penghambat dalam praktik pengajaran di kelas yang dilakukan guru memperoleh data sebagai berikut:

Faktor pendukung kegiatan pengajaran di kelas yaitu sebagai berikut:

1) Fasilitas yang sudah disediakan oleh beberapa sekolah seperti ruang komputer, akses internet sudah cukup memadai meskipun masih terbatas.

2) Informasi yang dibutuhkan guru dalam mendukung pembelajaran banyak di dapat di internet dan dengan mudah di dapatkan

3) Lingkungan seperti dukungan kepala sekolah sudah diberikan terkait dengan keberhasilan proses pembelajaran.

Sedangkan faktor penghambat yang terdapat dalam kegiatan pengajaran di kelas adalah sebagai berikut:

1) Faktor internal guru, seperti kemampuan guru yang masih terbatas, tidak ada inovasi dari guru dalam penyampaian pembelajaran didalam kelas, metode pembelajaran yang monoton, tidak cermat dalam melakukan perencanaan, pelaksanaan dan evaluasi pembelajaran dengan baik sehingga hasil belum maksimal, banyak yang belum mengetahui bahwa ada aplikasi-aplikasi yang dapat membantu proses pembelajaran menjadi menyenangkan terutama untuk guru usia lanjut.

2) Fasilitas pendukung masih harus ditingkatkan seperti LCD di setiap kelas beserta alat peraga.

3) Minat siswa dalam pembelajaran masih minim karena rendahnya 
Penggunaan Model Pembelajaran 4.0 Bagi Tenaga Pendidik ...

inovasi guru dalam praktik pembelajaran serta penggunaan metode belajar yang monoton.

\section{Pembahasan}

Revolusi industri 4.0 saat ini yang ditandai dengan semakin meningkatnya konektivitas mesin dan data yang mengubah berbagai sektor kehidupan salah satunya pendidikan yang ditantang untuk mampu memanfaatkan teknologi terutama internet dalam pembelajaran. Tetapi temuan di lapangan menunjukan bahwa masih banyak guru yang menggunakan model konvensional dalam kegiatan pembelajaran. Ciri khas dari model pembelajaran konvensional ini adalah teacher centered. Sanjaya (Ibrahim, 2017) menyatakan bahwa dalam model konvensional penggunaan ceramah menjadi metode penyampai utama. Peran guru yang mendominasi justru meminimalisir keterlibatan siswa dalam proses pembelajaran. Sehingga, siswa kurang mengeksplorasi pengetahuannya dan lebih banyak menyimak paparan guru. Artinya, kegiatan pembelajaran dalam model konvensional ini hanya berpusat pada kegiatan penceramah, dan komunikasi bersifat satu arah.
Berdasarkan penelitian Sukartono (Sukartono, 2017) menemukan bahwa saat ini pendidikan tengah mengalami transisi yang besar. Peran guru yang pada awalnya dipandang sebagai sumber ilmu kini berubah menjadi fasilitator kegiatan pembelajaran yang dituntut untuk inovatif menyajikan sebuah pembelajaran yang mendorong siswa sebagai pusat pembelajaran. Temuan penelitian ini sesungguhnya relevan dengan konsep pembelajaran 4.0 yang saat ini menjadi tuntutan guru dalam mengajar.

Berkaitan dengan paparan tersebut, saat ini guru dituntut memiliki kemampuan yang dibutuhkan dalam pendidikan 4.0 sebagaimana disebutkan Qusthalani (Utomo, n.d.), bahwa setidaknya ada lima kompetensi yang harus dikuasai guru di era revolusi industri 4.0 yaitu:

a. Educational competence yakni kompetensi pembelajaran berbasis internet sebagai basic skill.

b. Competence for technological commercialization yaitu seorang guru harus mempunyai kompetensi yang akan membawa peserta didik memiliki sikap enterpreneurship 
p-ISSN 2442-4544 | e-ISSN 2550-0252 || 51

DOI: $10.30997 /$ dt.v8i1.3342

dengan teknologi atas hasil karya inovasi peserta didik.

c. Competence in globalization yaitu guru tidak gagap terhadap berbagai budaya dan mampu menyelesaikan persoalan pendidikan.

d. Competence in future strategies yaitu kompetensi untuk memprediksi dengan tepat apa yang akan terjadi di masa depan dan strateginya dengan cara joint lecture, joint reserach, joint resource, staff mobility dan rotasi.

e. Counselor competence yaitu kompetensi guru untuk memahami bahwa ke depan masalah peserta didik bukan hanya kesulitan memahami materi ajar, tetapi juga terkait masalah psikologis akibat perkembangan zaman.

Selain kompetensi di atas, dalam pembelajaran berbasis 4.0 ini guru sebagai pendidik seyogianya mampu menanamkan nilai-nilai dasar pengembangan karakter pada diri peserta didik termasuk didalamnya mengenai pemanfaatan kemajuan teknologi informasi secara bijak (GTK, 2019). Hal ini menjadi bukti bahwasanya ditengah kemajuan dan tuntutan pembelajaran era 4.0 ini peranan guru peranan guru tidak dapat digantikan sehingga dirinya harus senantiasa terus mengembangkan potensi dan kompetensi diri guna menciptakan praktik pembelajaran yang selaras dengan tuntutan pembelajaran era 4.0.

Sebagaimana temuan penelitian bahwa evaluasi pembelajaran masih dilakukan secara konvensional yang kurang relevan dengan perkembangan siswa. Oleh karena itu, perlu diadakan praktik evaluasi yang memang selaras dengan perkembangan siswa sebagaimana yang tercantum dalam Undang-Undang Nomor 20 tahun 2003 pasal 53 ayat 1 menyatakan bahwa evaluasi hasil belajar sesungguhnya dilakukan untuk mendorong kemajuan dan mengetahui perkembangan hasil belajar peserta didik secara berkesinambungan (Undang-Undang No 20 Tahun 2003 Tentang Sistem Pendidikan Nasional, 2003). Berdasarkan hal tersebut jelas bahwa evaluasi yang saat ini dilakukan tidak lagi sesuai dengan kebutuhan. Adapun di era pendidikan 4.0 yang serba digital seperti saat ini praktik evaluasi harus dilakukan melalui media pembelajaran interaktif. Hal ini sebagaimana 
disebutkan Titiana dkk (Titiana et al., 2019) dalam penelitiannya yang menyatakan bahwa media pembelajaran interaktif berbasis teknologi ini sejalan dengan teori belajar Pavlov yang mengungkapkan bahwa penggunaan media pembelajaran interaktif akan melibatkan melibatkan stimulus respon guru dan siswa.

Guru memberikan informasi secara akurat dan menyenangkan, maka dalam proses pembelajaran dalam kelas siswa akan memberikan respon yang sesuai dengan stimulus yang diberikan guru dalam proses pembelajaran tersebut, Paparan materi yang didukung pemanfaatan media interaktif akan mendorong siswa untuk berkonsentrasi sehingga mampu mengerjakan evaluasi yang guru berikan. Berdasarkan hal tersebut maka praktik evaluasi berbasis teknologi media interaktif dapat mendorong terwujudnya proses pembelajaran yang efektif, efisien serta menyenangkan.

Selanjutnya mengenai faktor pendukung praktik pembelajaran di era 4.0 ini sekolah telah menyediakan sarana dan prasarana untuk menunjang pemutakhiran pembelajaran meskipun masih terbatas, kemudian dukungan kepala sekolah pun telah diberikan adapun keleluasaan dalam memperoleh informasi dan berinovasi pun diperoleh guru. Adapun faktor penghambatnya yaitu dari diri guru sendiri masih terbatas pemahaman mengenai praktik dan kompetensi yang dibutuhkan dalam pembelajaran era 4.0, kemudian sarana yang masih terbatas dan minat belajar siswa yang rendah. Menyikapi temuan tersebut, faktor pendukung seyogianya dipertahankan dan ditingkatkan guna mendorong para guru untuk terus belajar dan mulai mempraktekkan pembelajaran yang relevan dengan kebutuhan pendidikan 4.0 .

Adapun mengenai faktor penghambatnya perlu dilakukan tindakan untuk memecahkan permasalahan yang ada. Keterbatasan pemahaman guru mengenai praktik pembelajaran era revolusi industri 4.0 dapat ditingkatkan melalui kegiatan workshop atau webinar yang berupa bimbingan teknis praktik pembelajaran 4.0 (Gunawan et al., 2020). Adapun mengenai sarana dan prasarana, sesungguhnya dapat memaksimalkan sarana yang sudah ada melalui peningkatan kreativitas dan inovasi 
p-ISSN 2442-4544 | e-ISSN 2550-0252|| 53

DOI: $10.30997 /$ dt.v8i1.3342

guru. Peningkatan akan berimplikasi pada peningkatan minat belajar siswa dalam praktik pembelajaran di era 4.0 yang guru laksanakan.

\section{SIMPULAN}

Simpulan yang dapat diambil dalam penelitian yaitu:

1. Implementasi model pembelajaran yang dilakukan oleh guru-guru sekolah dasar DKI Jakarta masih belum maksimal karena guru masih dominan menggunakan metode ceramah dalam desain konvensional. Adapun penggunaan teknologi seperti aplikasi WhatsApp Group, digunakan hanya sebatas pemberian tugas dan bahan ajar yang sederhana sehingga tingkat inovasi pembelajaran masih terbilang rendah.

2. Evaluasi dalam proses pembelajaran di kelas oleh guruguru sekolah dasar DKI Jakarta masih belum maksimal sebab sebagian guru masih mengalami kesulitan dalam menggunakan evaluasi berbasis media interaktif dan jarang melibatkan penggunaan teknologi.

3. Faktor pendukung pembelajaran era 4.0 yang telah ada yaitu fasilitas berbasis internet meskipun masih dalam jumlah terbatas, dukungan kepala sekolah dan kemudahan mengakses sumber informasi mengenai praktik pembelajaran era 4.0. Adapun faktor penghambatnya yaitu keterbatasan pemahaman guru dalam menggunakan aplikasiaplikasi interaktif dan kurangnya inovasi dalam penyampaian pembelajaran, keterbatasan fasilitas serta minat belajar siswa yang cenderung rendah.

\section{UCAPAN TERIMA KASIH}

Ucapan terima kasih kepada Lembaga Penelitian dan Pengembangan Universitas Muhammadiyah Prof Dr. HAMKA yang telah memberi dorongan materil dalam penelitian ini.

\section{DAFTAR PUSTAKA}

Anggraeni, C. W. (2018). Promoting Education 4.0 in English for Survival Class: What are the Challenges? Metathesis: Journal of English Language, Literature, and Teaching, 2(1), 12. https://doi.org/10.31002/metathe sis.v2i1.676

GTK, S. (2019). Peran Guru Pada Era Revolusi Industri 4.0. Direktorat Jenderal Guru Dan Tenaga Kependidikan. https://gtk.kemdikbud.go.id/read -news/peran-guru-pada-erarevolusi-industri-40

Gunawan, I. G. D., Suda, I. K., \& 
Primayana, K. H. (2020). Webinar Sebagai Sumber Belajar di Tengah Pandemi COVID-19. Purwadita: Jurnal Agama Dan Budaya, 4(2).

Hanum, N. S. (2013). Keefektifan elearning sebagai media pembelajaran (studi evaluasi model pembelajaran e-learning SMK Telkom Sandhy Putra Purwokerto). Jurnal Pendidikan Vokasi, 3(1). https://doi.org/10.21831/jpv.v3i1. 1584

Hartati, M. S. (2019). PENGEMBANGAN METODE PEMBELAJARAN DALAM MENGHADAPI REVOLUSI INDUSTRI 4.0. Jurnal Global Citizen : Jurnal Ilmiah Kajian Pendidikan Kewarganegaraan, $7(1)$. https:// doi.org/10.33061/jgz.v7i1. 3061

Ibrahim. (2017). Perpaduan Model Pembelajaraan Aktif Konvensional (Ceramah) dengan Cooperative (Make-A Match) untuk Meningkatkan Hasil Belajar Pendidikan Kewarganegaraan. Suara Guru: Jurnal Pendidikan Sosial, Sains Dan Humaniora, 3(2). https:// doi.org/http://dx.doi.org /10.24014/suara\%20guru.v3i2.3597

Soenarno, S. M. (2019). Mastery of Pedagogical Content Knowledge for Students of Natural Science Education. Formatif: Jurnal Ilmiah Pendidikan MIPA, 9(2). https://doi.org/10.30998/ formatif. v9i2.2813

Sugiyono. (2018). Metode Penelitian Pendidikan. Alfabeta.

Sukartono. (2017). Revolusi Industri 4.0 dan Dampaknya terhadap Pendidikan di Indonesia. FIP PGSD Universitas Muhammadiyah Surakarta.

Titiana, E. S., Yolandini, B., Wiriyanti, K., \& Azizah, N. (2019). Guru
Transformers: Pembaharu Media Pembelajaran Di Sekolah Dasar Era Revolusi Industri 4.0. Prosiding Seminar Nasional Pendidikan FKIP UNTIRTA.

Undang-Undang No 20 Tahun 2003 Tentang Sistem Pendidikan Nasional, (2003).

Utomo, S. S. (n.d.). Guru di Era Revolusi Industri 4.0. In Lumbung Pustaka UNY. 